UDC 349.4 (477)

DOI https://doi.org/10.37687/2413-7189.2019.3.7

\author{
Sydor V.D., \\ $\mathrm{PhD}, \mathrm{DSc}$, \\ Professor of Constitutional, Administrative and International Law Department \\ of the Kyiv Institute of Intellectual Property and Law \\ of National University "Odesa Law Academy" \\ ORCID: 0000-0002-1794-2577
}

\title{
POSTREFORM TRENDS OF THE UKRAINIAN LAND LAW
}

\section{ПОСТРЕФОРМОВІ ТЕНДЕНЦІЇ УКРАЇНСЬКОГО ЗЕМЕЛЬНОГО ПРАВА}

The publication is devoted to identifying the main trends of the Ukrainian land legislation development. The land reform conducted in Ukraine, which legally formalized the change of the land system, economic priorities, ideology, requires a deep revision of the land legislation. Ukraine's entry into a new historical era necessitates a critical reassessment of past experience in the regulation of land relations, a theoretical understanding of the processes and phenomena taking place in the area of land use and protection, the development of new approaches to their study. Modern land legislation of Ukraine holds a special place in this context. Keeping some technical and legal succession of the Soviet land legislation, it is fundamentally different from it in its content and socio-political orientation, reflecting the specifics of the historical conditions of formation and development of modern land relations. Land legislation is one of the main instruments of democratic reform in Ukraine, but the theoretical aspects of these changes are not always well understood, which leads to their inconsistency and poor efficiency.

The claim that the main tendencies of the development of the land legislation of Ukraine are: unification and differentiation of the land legislation; penetration of land regulation into the sphere of legal regulation of other industries and, conversely, penetration of multi-sector legal regulation - into the sphere of land law regulation; ecologization of land legislation; strengthening legal liability for committing offenses in the field of land protection; development and improvement of land procedural legislation; harmonization of land legislation with European legislation.

Key words: land reform, land legislation, development trends, unification, differentiation, ecologization, land process, legal responsibility, harmonization.

Публікація присвячена визначенню основних тендениій розвитку новітнього земельного законодавства України. Проведена в Україні земельна реформа, щзо юридично оформила зміну земельного ладу, економічних пріоритетів, ідеології, вимагає глибинного перегляду земельного законодавства. Вступ України у нову історичну епоху зумовлює потребу в критичній переоцінці минулого досвіду регулювання земельних відносин, теоретичному осмисленні прочесів і явищ, що відбуваються в галузі використання та охорони земель, розробки нових підходів до їх дослідження. Сучасне земельне законодавство Украӥни в ичьому контексті займає особливе місие. Зберігаючи певну техніко-юридичну правонаступність радянського земельного законодавства, воно принципово відрізняється від нього своїм змістом і сочіально-політичною спрямованістю, щзо відображають специфріку історичних умов формування і розвитку сучасних земельних відносин. Земельне законодавство є одним з основних інструментів демократичних реформ в Украӥні, проте теоретичні аспекти иих перетворень далеко не завжди осмислені, щзо зумовлює їхню непослідовність $і$ низьку ефективність.

Обгрунтовується твердження про те, щчо основними тенденціями розвитку земельного законодавства України є: уніфікачія і диференціачія земельного законодавства; проникнення земельно-правового регулювання у сферу правового регулювання інших галузей і навпаки, проникнення багатогалузевого правового регулювання у сферу земельно-правового регулювання; екологізаиія земельного законодавства; посилення юридичної відповідальності за здійснення правопорушень у галузі охорони земель; розвиток та вдосконалення земельного процесуального законодавства; гармонізачія земельного законодавства із європейським законодавством.

Ключові слова: земельна реформа, земельне законодавство, тендениії розвитку, уніфікація, диференціація, екологізачія, земельний процес, юридична відповідальність, гармонізація.

Introduction. The dynamic development of the land law of Ukraine will not take place without its internal arrangement, which is characteristic of any system that seeks perfection. The fundamentally important for the development of the land laws are the processes of the integration and differentiation.

While using these objective processes the following generic areas of the legislation have developed: ensuring the unity of the regulatory and protective legislation, creation of an effective mechanism of the laws imple- mentation, more intensive development of the common institutions of human rights and freedoms, legal liability; formation of an effective legal mechanisms for the citizens and legal entities to fulfill their responsibilities to society and the state.

The land reform is directly affected by the problems of socio-economic and legal development of our society. A special role in their resolution is given to the appropriate land laws, its optimal ratio with other branches of the national legislation by taking into account such trends 
as the unification and differentiation. These are the two objective consequences that the modern legislative practice is largely characterized by. Being paired categories, they are so closely interrelated that their separate existence is impossible.

The aim of the publication is identifying the main trends of the Ukrainian land legislation development.

Content. Taking in the consideration the object of the legislative regulation, there are two basic approaches to the development of land laws - integrated and differentiated. Volume of the legal regulation of the related land relations in the framework of this or that approach is determined by the interests of the society at a particular period of its development and the objective to be achieved as a result of acts of the land legislation.

As part of an integrated approach the task of regulating of the social relations over land as a whole, as a single object is being achieved. The differentiated approach stands for the development of the legislation aimed to regulate various relations, including the usage and protection of the certain categories of the land. Unification is the process of creating, merging, integration of the norms in one source for the most complete and detailed legal regulation of the social relations. Search for new directions to the land reforms led legislators to adopt October 25, 2001 the Land Code of Ukraine - the main unified act of the land law, which aims to integrate land and legal norms.

Unification has a dual focus: on the one hand, the development of common regulations on the other competent technical and formalized understanding of the adopted provisions of unification, ie systematization. Publication of the general norms and legislative acts - only one of the components of this process, the legal basis for unification. These norms may be multi-dimensional in nature and function as definitions, declarations, rules, principles, general authorizations and general prohibitions. The unification allows us to cover the entire set of homogeneous social relations; avoid legal conflicts, avoid legal gaps in the regulation of the land relations, reduce the number of regulations, increase the level of the legal technology.

The unity and unification are not identical concepts. Unity is the hallmark of the land laws, and also reflects the common principles of the regulation of the land relations. Unification is a set of uniform methods of regulating land relations, with its main feature to be the internal unity, because these phenomena are inextricably linked. Unification of the land laws promotes simultaneous impact of all structural elements of the land laws, strengthens their interdependence. Monolithic system of the land laws is a legal basis for harmonization of the land laws, the need for which depends on the intensity of the accumulation of the required material.

The process of the differentiation has the opposite direction compared to the integration of the legal regulation of the land relations. The differentiated acts of the land legislation of Ukraine is a legal source and a form of expression of the norms of the land law, which is based on a differentiation of the regulation of the land relations.
Land laws of Ukraine contain some complex legal requirements and regulations that perform specialized functions. With their help the government is able to take into account the specificity, dynamics and diversity of the land relations. The differentiation is manifested in the lawmaking and law implementation processes and is characterized by the isolation of a homogeneous set of the social relations in order to regulate them in accordance with their specific requirements. The positive nature of the process of differentiation of land legislation can set the following main parameters: allows us to cover a wide range of legal influence of public relations, leads to the elimination of gaps in legislation, promotes more logically correct and perfect structure of the regulations, provides flexible, dynamic nature of the legal system, creates prerequisites for a competent legal training in the law enforcement practice [1, p. 17].

Differentiation is the process of creating sources, characterized by the isolation of a variety of the homogeneous land relations in order to their specific legislative regulation and taking into consideration the abnormalities of these regulations. The differentiation allows us to cover a set of homogeneous land relations that require special regulation to avoid legal conflicts and ambiguity in the regulation of the social relations and to enhance the legal technique.

The differentiation trend reflects the breadth of those land relations arising in the process of the land reforms.

In the relation of uniform and differentiated regulations of the land law one should not seek conflict, and even more they should not be opposed one to another. The prospect of the development of the land laws - in their reasonable understanding are combined. Uniformed acts form the core of the land laws, allow to secure common norms that reflect the land policy, and differentiated fill this policy with the real content, include the necessary specifics to the general rules.

It is important to realize that the process of unification and differentiation covers all the structural units of the land laws and are continuous in nature. Their usage in the different parts of the legislative panel is largely due to the presence of the preconditions of the unification and techniques of its implementation.

These conditions, in our opinion, should include: a high degree of the specialization of the land legislation, the need for harmonization of the legal material in the similar land relations, high level of functional relationships between the various institutions of the land laws and their conflict and so on. Unification of the law is a determined practice of the social development process in the regulation of these phenomena and the creation of the legislation or regulations affecting the status and the improvement of the legislation.

The important question of the development and improvement of the land legislation of Ukraine is the ecologization of its norms. At the present stage of world development the ecological factor is becoming increasingly urgent and a priority in the international relations, economic, scientific and technical cooperation of almost all countries. Therefore, further development of the 
social production in Ukraine should be accompanied by ecologization of all its branches based on the priority of the environmental and economic approach and the adaptation of the environmental standards of the European Union [2, p. 18].

Ecological requirements of the laws relate to all areas of the law without exception, but they are particularly relevant to the land law. Environmental compliance in the usage and protection of the land is crucial for the conservation of land resources and the environment. The principle of the land protection as a basis of the national wealth has been declared in the land legislation. The proclamation of the environmental priorities is being supported by a number of the legislative norms that develop environmental principles of the land usage and protection. Assessment of the land and the effectiveness of the planned measures for the land protection take into account the environmental expertise established by the sanitary law and other standards and requirements.

The increase of the negative pressure of the social life on the land natural potential requires the legislator to introduce tighter ecological land rights, ie closer binding of these rights and responsibilities to the environmental protection and restoration of the land. Land usage depends on the objective requirements of the nature existence. The nature of the process of exploitation, land usage, their boundaries have an environmental focus. All this is due to the mandatory compliance with the rules of both the land usage, and other natural resources, which are inextricably linked to the land, the observance of the standards of environmental safety, maintaining earth's soil surface, protecting the land from erosion and other unfavorable processes.

Ecologization of the legislation and law is the process of the implementation of the environmental requirements in the legislative and other norms governing the economic and other activities which affects or may affect the environment. Ecologization as an activity aims at the implementation of the environmental requirements, covering virtually all areas of the production, social and domestic life, which is caused by the priority of laws of nature, which all must adhere to in the process of economic and other activities which affect the state of the environment.

The goal of the ecologization of the legislation is to provide rules and norms of the construction planning and land usage, norm-legislative acts or the normative documents, technical and economical and other specifications and other rules and regulations of the ecological character. These standards include health, construction, technology, urban development standards approved by the competent authorities.

Ecologization of the land legislation is done through: the implementation of the environmental laws in the legal regime of the various categories of the land; ecologization of the legal status of the subjects of the land relations; ecologization of the property and means of production, as landowners and land users while exercising their rights to land are obliged to take measures to prevent land degradation and pollution of the environ- ment; ecologization of the techniques and technologies implemented in the field of the land usage.

One of the pronounced trends in the development of the land legislation is the strengthening of the legal responsibility for offenses in the field of land protection. Lack of the effective land legislation creates favorable conditions for the development of the shadow economy and generates violations of the law and therefore causes significant losses to the state. The weakening of the regulatory role of the state led to a situation where the violations of the requirements of land legislation take place to fulfill the economical and personal interests of people. Offenses, particularly acquisitive crimes, are related to trafficking of land resources in the country is the result of actions of a complex of factors and constitute a significant threat to the development of the land relations.

Since the state and society desire that rules of land law should be voluntarily and conscientiously performed, the legislation established measures of coercion and punishment in the form of the complex mechanisms of legal liability.

Legal responsibility - not the main measure to ensure the rational usage of the land. There are norms that are not legal liability ones, which perform the important function of ensuring the rational usage of the land these are the norms of a preventive nature, termination and restoration of the land legislation. Even the strictest sanction provided for the damage of the land, cannot eliminate those harmful consequences that come as a result of the offense. Therefore, more attention should be paid to measures of not legal responsibility,but the organizational measures - state control over the usage and protection of the land, state land cadastre, improvement of the land usage planning, simplifying the procedure for granting and withdrawing land from others.

Unlike preventive measures termination occurs during the execution of the offense and it is a reaction to the illegal actions of the offender of the land legislation. Recovery as a way to deal with the violations of the land legislation aimed at eliminating negative effects of the land offense. Forms of the restoration of the broken laws are different and depend on the nature of the offense: it may be the elimination of the unlawful refusal to grant land, restoration of the previous state of the damaged land and so on.

The violation of the land law, the failure or improper fulfillment of the land legisolative norms has a negative impact on the land usage and protection. Therefore, the most important element of the legal rational usage and protection of land, guarantying rights and lawful interests of the land owners, land users is the use of the legal means of influence to eliminate the violations of the land legislation and the termination of their occurrence in the future, the restoration of the broken law and bringing perpetrators of crime to the land legal liability.

Land liability is an effective mechanism to stimulate compliance with the law of the land. The most worked out type of the legislative liability for the breaking the land law is the compensation for the damage caused by the land offenses, because like other forms of liability, it 
is based on the specific and proven long-term practice of the Civil Code of Ukraine.

The land offenses can be divided into minor and dangerous to the state and society by their negative effects. The legal framework governing the administrative liability for violations of the land legislation is to be improved by the amendments of the existing or the adoption of new norms that will cover all the basic and fundamental issues of the legal regulation of these relations according to their nature and content. The Law of Ukraine, adapted on April 15, 2008 has strengthened the administrative responsibility for the distortion or concealment of the data of the government cadastre, removal and transportation of the soil covering without a special permission, violation of the terms of the return of temporarily occupied lands or non bringing them in the condition suitable for its intended usage, unauthorized deviation from the land management projects [3].

The problems of improving the legislation on the administrative responsibility for the violation of the land legislation is to: prevent the inclusion of the new formulations of administrative offenses without reasonable enough practice grounds; to provide an unambiguous application and interpretation of the Code of Administrative Offences, in which norms have been formulated quite generally and require broad administrative effect, so they must rely on the requirements of Ukrainian Land Code.

Regarding criminal liability for violations of the land legislation, the Criminal Code of Ukraine is art. 239 "Contamination or deterioration of the land" with significant penalties (including the penalty of the deprivation of the liberty for a term of two to five years) referred for committing a crime [4]. Requirements to change or amend it do not exist, because the number of criminal cases can be counted in tens and the number of offenders held accountable can be measured only by simple numbers. The social danger of the offense of pollution or damage of the land has not yet been realized by the public.

The problem here is not so much to improve the legislation, but it lies in the law enforcement: to ensure the inevitability of the criminal sanctions for pollution or damage of the land which is a public danger; it must be distinguish from the damage and contamination of the agricultural and other lands under Art. 52 of the Code of Administrative Offences.

The improvement of the legislation promotes the functioning of the legal system as a whole organism, organic entity that produces an effective, comprehensive, systemic impact on the public life.

Study of the land legislation through the formal legal method allows to conclude that the lack of procedural norms that would facilitate the implementation of a number of substantive land laws. In the land legislation major role in the legal regulation of the social relations play a relevant substantive law. They determine the nature of the land relations, the content of the rights and duties of subjects of the land law concerning the land. But the primacy of the material legislative norms can not be a reason for the land legislation not to include proce- dural norms that create the necessary legal forms of the material norms implementation. Without them there is no guarantee that the material norms will be implemented correctly according to their content.

Important role in protecting the rights and legitimate interests of citizens in the land and related property cases is owned by the legal courts.

The norms governing the land and procedural relationships of the land constitute the legal process, the legal nature of which is that it is settled by the procedural law procedures to address individual specific cases involving government land fund in the course of which there are numerous legal relations, which are regulated by the land procedural rules. The land legal process is the appropriate activity of the land and other executive and administrative authorities applying the norms of the material land law. This order of activity is associated with the settlement of the specific individual land cases. The land legisolative process is a way of the implementation of the material norms of the land law.

Besides that, the land legislative process represents the activities of the land jurisdiction which quickly and correctly solves land disputes with the protection of the inviolability of the property rights to land, subjective rights and interests of the landowners and land users, rational usage, restoration and protection of the land.

Land process is a set of the settled land and the procedural norms of the legal activities (including resolving land disputes), carried out by the authorities to solve individual and specific land issues. The state and local governments as agents of the land-procedural relations must perform the task of the developing and improving a transparent procedure of the alienation of the land parcels, giving individuals and legal entities the choice of different types of the functional land usage, development of the mechanism of the acquisition of the land rights on competitive basis. The state and local governments are required to form the necessary market infrastructure, to ensure its functioning, to create conditions for competition, transparency and the legality of the land transactions.

The development of Ukraine's legal system, the transformation of objects and methods of different areas of law, the permanent reform of virtually all spheres of social life, the implementation of the land reform, the need to adapt European Union legislation to make constant adjustments to the question of the actual belonging of the certain phenomena of land to the legal sphere, including the scope of regulation standards with the land law. Therefore, an important trend in the development of the land law is its harmonization with European legislation. Harmonization can help achieve a functional balance of the legislative acts to ensure the degree of balance between them, allowing the legal system to function and thrive in a given direction.

Harmonization is accompanied by the strict legal means - the abolition of acts, their contestation, invalidation and finding them soft - aligning the acts with their constitutional provisions, reorganization of the legal consultation programs and more. 
Adaptation of the Ukrainian land legislation to the European Union land legislation - is the gradual adoption and implementation of the norm-legislative acts of Ukraine tailored considering the EU legislation. In the National Adaptation Program of Ukraine priorities should be given to the legislative acts of Ukraine, harmonization of the relevant EU legislation will provide the legal measures to protect the environment and the adequate environmental usage.

Conclusions. The process of harmonization of the land laws must be based on evidence-based concepts, defining the purpose and objectives of this process. With the help of harmonization it is important to solve complex tasks constantly, which include a selection of the norm-legislative acts of the land legislation of Ukraine and the EU, performing their comparative legal analysis to identify conflicts and gaps, as well as estimation of the advantages considering the positive experience of the land legislation. Based on the findings the recom- mendations were made to eliminate inconsistencies in the legal regulation of the land relations.

Ongoing Ukrainian legal land policy is aimed to bring the land legislation in line with the latest international standards, including the standards of EU member states. As a result of the land reform and associated land reform legislation the institutions of private, communal and state ownership of land, the land market institution, the institution of state registration of rights to land property, etc. of such content have developed, with which these institutions operate in the EU land legislation.

In the process of improving of the land legislation with regard to European integration of Ukraine, it is important to take into consideration the experience of the regulated land relations in the EU countries. In the lawmaking activities one should use the integration processes more often and take into account the positive experience of the legal regulation of the land issues developed by the democratic states, which are close to Ukrainian legal regulation.

\section{References:}

1. Сидор В.Д. Теоретичні проблеми розвитку земельного законодавства України : автореф. дис. ... д.ю.н. спец. 12.00.06 ; Інститут держави і права ім. В.М. Корецького НАН Украни. К., 2012. 36 с.

2. Костицький В.В. Економіко-правовий механізм охорони навколишнього природного середовища: теорія та практика : автореф. дис. на здобуття наук. ступеня д-ра юрид. наук : спец. 12.00 .06 ; Ін-т держави і права ім. В.М. Корецького НАН України. Київ, 2004. 52 с.

3. Про внесення змін до деяких законодавчих актів України щодо посилення відповідальності за порушення вимог земельного законодавства : Закон України від 15 квітня 2008 року N 271-VI. Голос України від 07.05.2008. № 87.

4. Кримінальний кодекс України від 5 квітня 2001 р. № 2341-III. Відомості Верховної Ради України. 2001. № 25-26. Ст. 131. 